\title{
ALBERTO REX GONZÁLEZ, RECONOCIMIENTO A SU EXCELENCIA EN LA ARQUEOLOGÍA ${ }^{1}$
}

\author{
Mario A. Rivera ${ }^{2}$
}

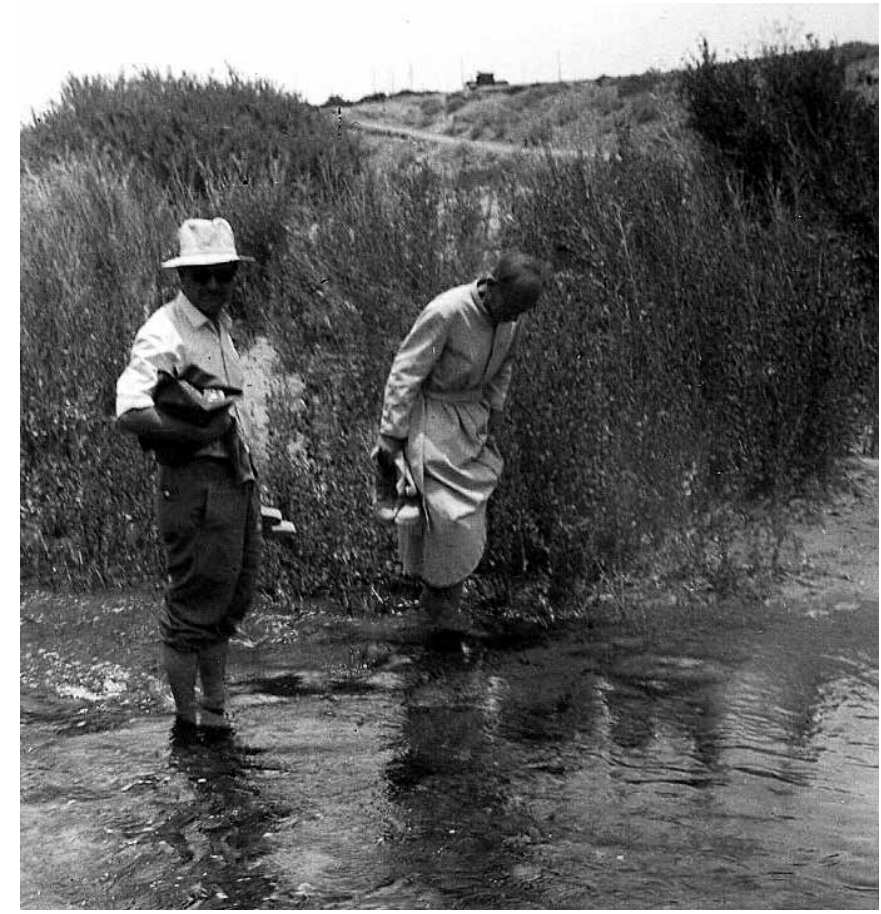

Alberto Rex González y Gustavo Le Paige, en un vado del Vilama. Primer Congreso de Arqueología en San Pedro de Atacama, Chile, en 1963 (foto cortesía de Mario A. Rivera).

Con gran congoja hemos recibido la noticia del fallecimiento de Alberto Rex González. Tuvimos a lo largo de los años una gran amistad. Compartimos experiencias en numerosas ocasiones y hasta último momento mantuvimos comunicación a pesar de la distancia en que nos encontrábamos. Rex fue para mí un gran consejero pues su experiencia me delineó un derrotero en mi propia carrera profesional que llegó a la obtención de mi doctorado. Tuve mi primer contacto con Rex siendo joven estudiante a raíz del Congreso de Arqueología que se celebró en San Pedro de Atacama en 1963. A partir de esa circunstancia, Rex nos puso en contacto junto a otros compañeros de Chile, Argentina y Perú, pues ante todo formábamos parte de una misma generación que comenzaba a descubrir el poder de la arqueología como profesión. Siguieron los años y mis pasos se fueron entrecruzando con los de Rex. Mientras estudiaba en Madison, EE.UU., con alegría y orgullo escuché su clase magistral cuando nos visitó en 1966. Más tarde, ya como colegas, compartimos en numerosas ocasiones, pero recuerdo con especial cariño nuestra experiencia en el Congreso Centenario de la Sociedad de Americanistas en París y luego su extensión en el Congreso de Ciencias Prehistóricas en Niza, donde la representación de Latinoamérica la componíamos sólo tres arqueólogos. Juntos visitamos los más importantes sitios del paleolítico

1 Parte de las palabras contenidas en nuestra solicitud a la Sociedad Americana de Arqueología en 2008 para postular a Alberto Rex González al Premio de Reconocimiento a la Excelencia de la Arqueología Latinoamericana y del Caribe.

2 Adjunct Professor Anthropology, Beloit College, Wisconsin. Research Associate Field Museum, Chicago, USA. marivera41@gmail.com 
del Mediterráneo, obteniendo una visión increíble del desarrollo de la ciencia prehistórica en Europa por los años 70. Gran amigo de otro de mis mentores, Junius Bird, tuve la enorme satisfacción de tenerlos juntos dictando una serie de conferencias en la Universidad de Chile de Antofagasta en 1980. Los años pasaron y las circunstancias políticas del país me trajeron de regreso a EE.UU., pero nuestros contactos continuaron fortaleciéndose. Fue instrumental para mi estadía por un año completo en Buenos Aires desarrollando un proyecto sobre Tiwanaku como investigador de CONICET en 1990. Asistimos juntos a los Congresos de Americanistas de Bogotá y Amsterdam, así como a varios congresos y reuniones internacionales en Perú, Bolivia, Chile y Argentina. Seguí sus pasos en el Instituto Arqueológico Alemán, donde dejó una marca indeleble, luego en la Universidad de Bonn, compartiendo con nuestro querido amigo y colega Udo Oberem, en el Instituto Iberoamericano de Berlín, en la propia Dumbarton Oaks en Washington D.C., el Museo Field de Chicago y el Museo Americano de Historia Natural de Nueva York. Hace unos años, con ocasión de su homenaje en Buenos Aires, me envió un emotivo mensaje en que recordaba nuestras experiencias conjuntas. En fin, con Rex se va el último miembro de una generación deslumbrante para la Arqueología Americana y para nosotros, que representamos sus genuinos discípulos, una lamentable pérdida.

El Dr. González es tal vez la principal figura de la Arqueología Sudamericana. Originalmente médico de profesión titulado en la Universidad Nacional de Córdoba (Argentina) prosiguió luego estudios en la Universidad de Columbia recomendado por Julian Steward y Wendell Bennett y siguiendo consejos personales de Alfred Metraux. Allí, el Dr. González fue parte de una de las generaciones más recordadas de antropólogos. Recibió su título de Doctor en Filosofía del Departamento de Antropología en 1948, siendo el primer arqueólogo sudamericano en obtener su grado doctoral de una universidad norteamericana. A su regreso a Argentina fue nombrado profesor en la Universidad Nacional del Litoral en 1953. Trabajó en distintas instituciones en su país, como la Universidad de Córdoba, Universidad de La Plata, donde llegó a ser Director de la División de Arqueología del Museo de Historia Natural, y Director del Museo Etnográfico de la Universidad de Buenos Aires (1984-1987). Participó activamente como
Presidente en la organización del $37^{\circ}$ Congreso de Americanistas (Buenos Aires 1966). Igualmente, fue miembro activo de la Sociedad de Americanistas, institución responsable de estos congresos. Tuvo participación crucial, como vicepresidente o secretario, de los Congresos de Americanistas de Costa Rica (1959), Viena (1976), México (1962 y 1974), Sevilla y Madrid (1964), Roma (1968), Lima (1970), París (1976) y Bogotá (1985). Jugó, además, roles importantes como consultor de UNESCO en la implementación de programas sobre manejo del patrimonio cultural en proyectos en Nubia (Sudán), Incallajta (Bolivia) y Cuzco y Puno (Perú). Fue profesor visitante en la Universidad de Harvard (1966-1968), Fellow en el Wilson Center for Advance Research en Washington (1987), Fellow del Instituto Alemán de Arqueología, Bonn (1989) y Guggenheim (1959 y 1966).

En 1999 recibió la Medalla Bicentenaria del Smithsonian Institution. Recibió además doctorados honorarios de la Universidad Nacional de Tucumán, Universidad Nacional de La Plata, Universidad Nacional de Córdoba, Universidad Nacional de Salta, y el título de Investigador Emérito de CONICET, Argentina. En 1986 recibio el Premio del Cincuentenario de la Sociedad Americana de Arqueología por su Destacada Contribución a la Arqueología Americana.

Seguramente una de las contribuciones más importantes del Dr. González ha sido su enorme influencia en el desarrollo de programas de educación superior en antropología y arqueología dispuestos para preparar a cientos de jóvenes estudiantes que tiempo después han sido instrumentales en el gran desarrollo de la arqueología argentina y sudamericana. En este aspecto, su autoridad y liderazgo ha sido crucial en la organización de los nuevos congresos de arqueología argentina que comenzaron a reunirse en los años 70. A raíz de estas acciones, no sólo los programas de pregrado se multiplicaron en diversas universidades, sino también comenzaron a implementarse programas de postgrado con el ofrecimiento de grados de doctorado. Esta influencia pronto fue replicada en otros países latinoamericanos, llegando a constituirse los estudios arqueológicos tan populares como otras disciplinas más conocidas en la región. Durante sus más de 70 años de práctica arqueológica, las principales preocupaciones del Dr. González fueron la defensa del patrimonio cultural, la protección de los derechos de los pueblos 
originarios y el desarrollo de políticas científicas. Sin duda su inquietud dominante que inspiró todos sus trabajos y que constituyó el principal eje que articuló toda su producción científica fue su interés en el problema de la evolución, una noción que él mismo consideraba haber heredado de Florentino Ameghino, el reconocido científico argentino. Rex combinó de manera maravillosa sus intereses sobre arte, cazadores y recolectores, etnografía, metalurgia, biología humana y museología.

Publicó extensamente sobre una gran cantidad de temas. Tal vez sus contribuciones más importantes son sus investigaciones sobre las Cuevas de Intihuasi y Ongamira, las culturas Tafi y La Aguada y sus obras monumentales sobre Argentina indígena Vísperas de la Conquista (1972, con José Antonio Pérez), Arte Precolombino de la Argentina (1977 y 1992), Las Placas Metálicas de los Andes del Sur, Contribución al Estudio de las Religiones Precolombinas (1992), La Cultura de La Aguada del Noroeste Argentino, Arqueología y Diseño (1998) y varios artículos sobre aspectos etnográficos.

Creemos que su dedicación al desarrollo de la arqueología en Argentina, sus contribuciones a nuestro entendimiento de la prehistoria de Sudamérica y la calidad de sus investigaciones destacan a Alberto Rex González como un miembro deslumbrante de la Arqueología Americana.

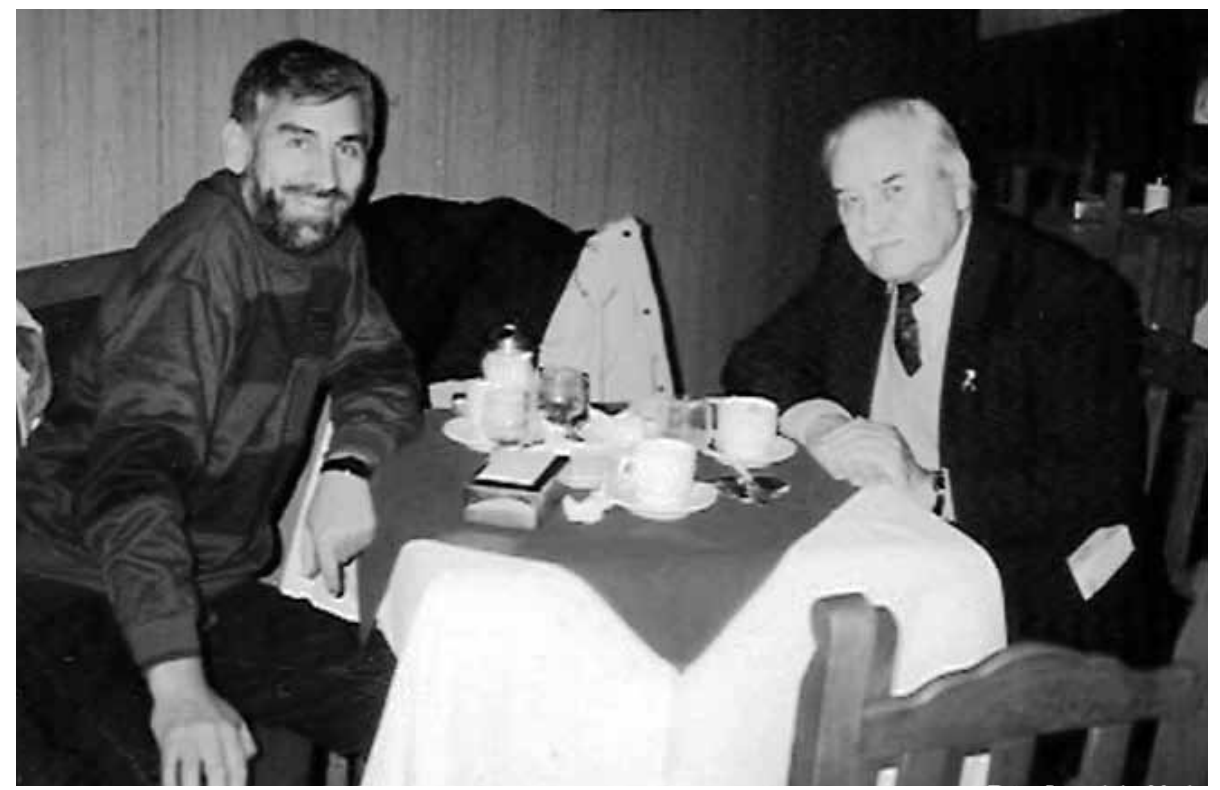

Mario Rivera y Alberto Rex González. Congreso de Arqueología Argentina en San Rafael, Argentina, en 1994 (foto cortesía de Mario A. Rivera). 



\title{
ALBERTO REX GONZÁLEZ, DEAN OF SOUTH AMERICAN ARCHAEOLOGY ${ }^{1}$
}

\author{
Tom D. Dillehay ${ }^{2}$
}

Dr. Alberto Rex González was an Argentine archeologist and anthropologist who I knew for more than thirty years. His intellectual and professional achievements and influences are highly worth honoring and remembering here.

Dr. Alberto Rex González was the Dean of southern cone South American archaeology and the founding father of modern Argentine archaeology. For over 60 years, his experience in archeology focused on the first human populations in the southern cone, the beginnings of complex societies in the Andes, and the art and symbolism of those societies. He supervised, oversaw, or helped to arrange archeological excavations at sites all over Argentina. Rex's long distinguished career in anthropological archaeology established the first basic chronology for most of Argentina. He meticulously documented cultural sequences for contiguous regions in Northwest Argentina, northern Patagonia, southern Bolivia, and northern Chile, and once radiocarbon dating became more available in the 1950s and 1960s, he was able to substantiate the timing of migrations and diffusions over considerable distances. He also was one of the major players in the debates surrounding the development and application of the period/ horizon style concept in Andean archaeology. Yet, his interests were not purely in formal chronology and phase building. Early in his career, he was concerned with questions of diffusion, migration, environmental change, political economy, symbolism, and others. As a consequence, he helped to place the archeology of Argentina and particularly Northwest Argentina on the South American map and in the international arena.

Although his archeological and anthropological research were largely concentrated in Argentina, his professional visits and talks and his widespread development of students and protégés in neighboring countries such as Chile, Bolivia, and Uruguay made him an international figure. A man of great wit and warmth, as well as learning, he trained generations of anthropologists, archaeologists, and historians. He was a master synthesizer, and his major works contained many of his most provocative and influential writings. Outside of South America, he was perhaps best known for his research into the Formative cultures of Northwest Argentina, the La Aguada post-Formative culture, and art and iconographic analyses of a wide range of archaeological materials.

For many of us, one of the most important features of Rex's approach to anthropology was that he always maintained an empirical dimension without becoming atheoretical. He was always focused on data collection, which necessitated intensive and extensive fieldwork. Beginning in the late 1940s, Rex built on the work of other scholars to establish the basic groundwork for an understanding of the major attributes of several important cultures, including Tafi, Cienega, Condorhuasi, Belem, among others. His field collaborations with other scholars were of such scope that many widely used terms for archaeological cultures derive from these investigations. Terminologically, then, he leaves an indelible imprint on the archaeology of South America. He also laid the empirical and theoretical groundwork for understanding one of the earliest complex societies of Northwest Argentina -the La Aguada culture.

In recent decades, González's middle-range theoretical interests in comparing and dating cultures led him to pioneer innovative ways of analyzing artifacts. To trace relatedness and change in cultures through ceramic classification, for instance, he defined many type-variety ceramic models in Northwest Argentina. For González, the comparative

$1 \quad$ Nota del Editor: Este comentario/obituario está basado en una carta de apoyo a la postulación de Alberto Rex González al premio Lifetime Achievement Award Society for American Archaeology enviada por el autor al comité ad hoc de la Sociedad Americana de Arqueología en diciembre de 2008.

2 Rebecca Webb Wilson University Distinguished Professor of Anthropology, Religion, and Culture and Professor of Anthropology and Latin American Studies, Department of Anthropology, Vanderbilt University, Nashville, TN 37325, Tel: 615-3228379. tom.d.dillehay@Vanderbilt.Edu 
analysis of ceramic and iconographic styles was fundamental to space-time systematics and the identification of migrations, diffusion, culture change, and the rise of social complexity. Other remarkable achievements in his career included excavations in numerous archaeological sites. In many of these excavations, he documented for the first time the existence of Formative and later cultures. The cultural sequences in regions where he worked are more complete, better dated, and largely have withstood the test of time better than those in the stamping grounds of other archaeologists. To be sure, as more sites are excavated and dated, the chronologies established by González have been refined, but the overall frameworks are still in place. In recent years, younger scholars armed with new concepts and approaches have reinterpreted the data and chronologies and developed new models. Yet, his work still provides the cultural historical framework within which new explanatory models are being developed.

Despite the major redirection in his studies from the reconstruction of culture history to anthropological theory and broad cultural syntheses over the past sixty years, he remained consistent with the goals he projected half a century ago, that is, to expose the cultural variability in the prehistoric record of Argentina, to study and explain processes of long-term change, and to move beyond the limitations of the language of ethnographic description. Many scholars may challenge Dr. González's interpretations of regional culture history and his understanding of human nature, but the fact is few any longer attempt to write cultural syntheses from the holistic perspective he did. I tend to trust his kind of interpretation as opposed to more ambitious ones based on little data and on a singular conceptual or theoretical explanation.

For Dr. González, as with many other archaeologists, anthropology was aesthetically, not just intellectually appealing. Although I never discussed the issue with him, I always had the impression that anthropology to him was a source of delight, adventure, and social experience, a liberating disciplined way of understanding the world and enjoying life as well. During my various trips to Argentina, I would accompany colleagues to the field in the vicinity of Tucumán, Jujuy, and Catamarca. We almost always encountered individuals in these areas who had excavated with "el Doctor" and remembered their experience with him very fondly.
To Dr. González, no division exists between anthropological and archaeological research. It is apparent in all of his works that he thought of research holistically, following the model of knowledge that developed through his archaeological research, through his contact with indigenous peoples, and through his formal academic education in different countries. In his primary emphasis on data, his readiness to combine the methods and perspectives of ethnography, ethnohistory, archaeology, and allied fields, and in his focus on culture history and general theory in the social sciences, he exemplified what I believe to be essential in anthropological scholarship. In short, all information and perspectives were grist for his intellectual mill. Despite many theoretical changes in the discipline over the past 40 years and most recently the shift to postmodernism, he was an unwavering proponent of the holistic and empirical approach to anthropology. And although his work had been concentrated in the southern cone of South America and more specifically Northwest Argentina, it is of immense importance to the discipline as a whole.

Individually and collectively, the publications of Dr. González represent a distinctive stance with respect to the theory, method, data, and practice of anthropology. The diversity of research programs that he undertook is clear in the publication of his book on Arte y Estructura (1974), which examines the cultural relationship between art -especially the feline motif- symbolism and the emergence of complex social systems. In the last twenty-five years of his research, he turned especially toward the cognitive and aesthetic dimensions of his data. Perhaps this grew out of old abiding interests, ones that had originally attracted him to archaeology. Always thinking broadly and comparatively, Dr. González noted the similarities between the $\mathrm{La}$ Aguada feline iconography and that of the Peruvian late Nazca polychrome pottery. He also saw a sharing of the treatment of trophy-head representations in the two styles and broader transAndean connections. His work on Andean symbolism and on indigenous cosmology still stands as classics in the discipline. Some of these works are fine examples of pioneering research in ethnoarchaeology and cognitive anthropology. He also published two other tomes. These volumes are Cultura La Aguada: Arqueología y Diseños (1998) and Las Placas Metálicas de los Andes del Sur: Contribución al Estudio de las Religiones Precolombinas. KAVA 
Materialen. Band 46. Komission fur Allgemeine und Vergleichende Archaeologie des Deutschen Archaeologischen Institut (1992). These are massive works that combined detailed empirical data, interdisciplinary methods, and rich theoretical insights into the power, authority, and symbolism of late complex societies in Andean Argentina. In addition to these books, he published numerous other volumes and hundreds of research articles in international journals.

In summary, from his various academic and field experiences and publications, he elaborated the fundamental approach to the study of southern Andean anthropology. A feature of his basic approach to anthropology was his constant consciousness of the history and structure of the discipline itself, and particularly of national scholarly identities. $\mathrm{He}$ keenly fostered the development of professional anthropology in Argentina and indirectly in several other South American countries. Perhaps more than any other South Americanist of his era, he promoted the development of institutions, individual scholars, and scholarly ties between the Andean countries in the west and the lowland countries in the east. He worked hard to break down national borders by offering formal and informal instruction in local settings and by helping students to find educational and field opportunities.

Aside from his theoretical and methodological innovations, González had a characteristic inspiring effect on other researchers, particularly younger researchers. Several major figures in Argentine and Chilean archaeology worked with him and served as his protégés. He produced numerous Ph.Ds, and he touched many lives of archeologists, including my own when I lived and worked in Chile during the Pinochet years. He was always encouraging and supporting. During those years in Chile, he often traveled to Santiago where he gave lectures and informal discussions. He induced a very relaxed and engaging intellectual atmosphere in these sessions, and he presided over them with good sense and wit. Argument was encouraged; there was never any "putting down" of anyone; one came away with the feeling that it had been enjoyable learning.

Intellectually, González was inquisitive and insightful; a careful reader who enjoyed making up his own mind about issues and encouraging others to think things through equally carefully. He had a keen nose for what the critical issues were. And he had an air of mature eagerness and personal self-confidence, and an ability to communicate that he knew what he was talking about without implying any comparisons to others or a lack of interest in what others had to say.

An amicable man, he was always generous of his time to all who wanted to confer with him. $\mathrm{He}$ also helped several women on to influential careers, encouraged the work of several non-Latin Americans working in Latin America, and initiated collaborations with colleagues form other countries. His collaborations reached beyond academe to also include vocational archaeology.

When one not ones look to the many disciples produced by Dr. González over the decades, you can see his influence. The works of his ex-students and close colleagues demonstrate the many facets of his contributions to anthropology. Their primary concern always seems to be to base their interpretations on empirical data and, either explicitly or implicitly, to ask what the past means to the present and how best to reconstruct and interpret local histories. His students recognize -even celebratethe importance of new data, fresh description, and basic analysis; they do not deny the importance of theory, but they recognize that its proper use requires rich data and elaborate analysis. Put simply, many of these disciples are an extension of Alberto Rex González -they adopt a historical perspective on every issue and freely blend ethnographic, historical, and archaeological data. That they do so with such diversity bears witness to the great scope of his impact on the field. His work and their work deserve the widest possible audience.

Reflection on his career as an archaeologist, anthropologist, and teacher can leave no doubts to the immense impact he had on the profession and to South American archeology. I know from many conversations with his students that they recall him as a teacher who inspired them in many different areas of anthropology. His colleagues remember him with a respect of extraordinary proportions and with a large debt of gratitude for the countless ideas he freely shared in many cooperative research ventures and books and articles.

During the last several years of his scholarly career, Rex González continued to pursuit knowledge in history, iconography, and cultural history. Everywhere he went he would seek out local archaeologists and friends through a practice session in the historical anthropology of the region. He always displayed his own special blend 
of historical seriousness and anthropological play. He was enormously inquisitive. In his writings, he saw monuments, buildings, and other historical sites as the markers of ways in which memory and history collided and then combined, requiring serious attention both to the quotidian nature of the lived world and its multiple historical determinations. Rex wore his learning with lightness and grace, but along with the originality and influence of his publications, he had a wit and capacity to engage both young and old scholars. He gave us models about how to do -as well as to conceptualize- historical scholarship, but he also gave a model of how to be a scholar in the world. All of us interested in Andean archaeology and of Latin America more generally must walk in his shadow for a very long time to come.

To close, Dr. González was a warm and generous person who cared much for his discipline and for friends and colleagues. He was an unstoppable researcher. Even in his early eighties he continued to study and to publish. It is no exaggeration to say that Alberto Rex González was truly one of the most knowledgeable and high-powered anthropological archaeologists who has ever worked in South America.

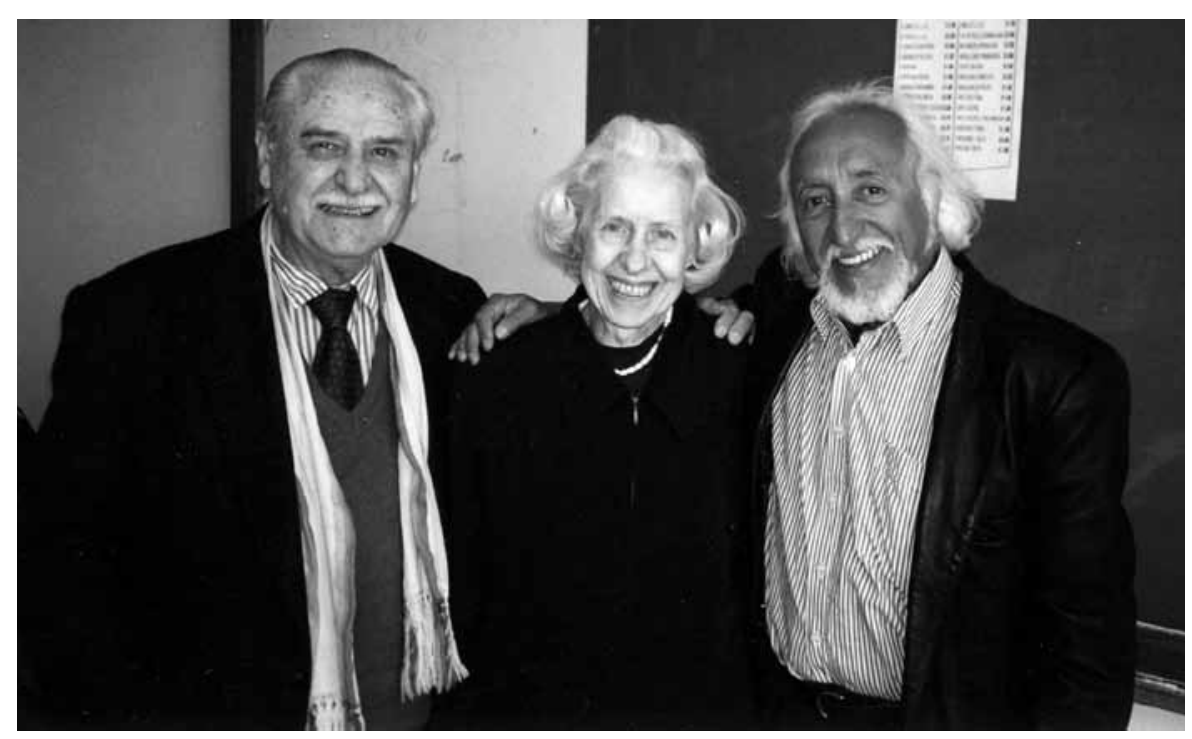

Alberto Rex González junto a Betty Meggers y Lautaro Núñez. Simposio sobre el periodo Formativo de la arqueología sudamericana organizado por el Instituto Smithsoniano y la Organización de los Estados Americanos, Cuenca, Ecuador, 1992. Gentileza Proyecto Archivo Digital Dr. Albert Rex González (Convenio CONICET - Museo Etnográfico J. B. Ambrosetti (FFyL, UBA) - Familia González). 